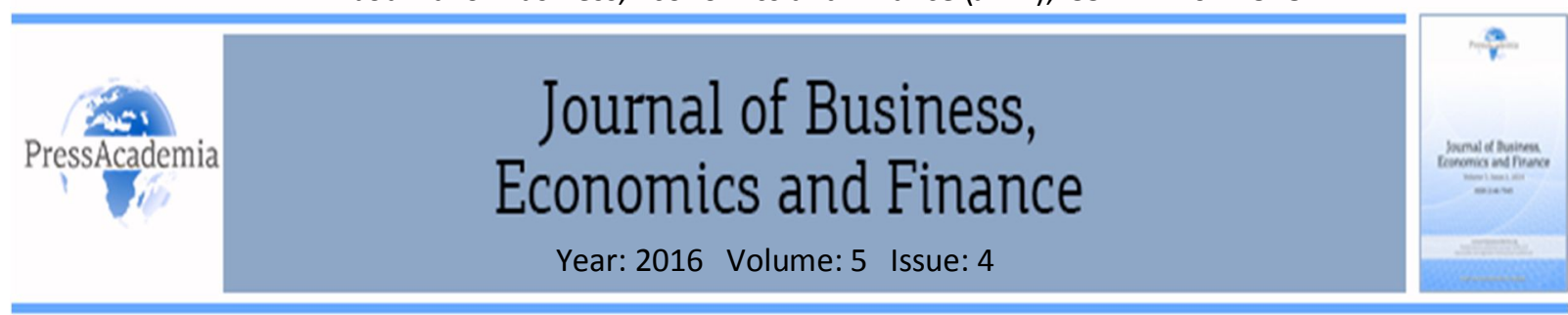

\title{
THE RELATIONSHIP BETWEEN EXCHANGE RATE AND INFLATION: THE CASE OF WESTERN BALKANS COUNTRIES
}

\section{DOI: 10.17261/Pressacademia.2017.358}

\author{
Besnik Fetai ${ }^{1}$, Paul Sergius Koku ${ }^{2}$, Agron Caushi ${ }^{3}$, Ariana Fetai ${ }^{4}$ \\ ${ }^{1}$ South East European University, b.fetai@seeu.edu.mk \\ ${ }^{2}$ Florida Atlantic Universityi, koku@fau.edu \\ ${ }^{3}$ South East European University. a.caushi@seeu.edu.mk \\ ${ }^{4}$ South East European University. af19577@seeu.edu.mk
}

\begin{abstract}
The paper investigates empirically the relationships between exchange rates and inflation in Western Balkan countries. The literature on the transition countries has recently focused on exchange rate as a shock absorber and downplayed its costs to macroeconomic stabilization. However, the decision to apply a different exchange rate regime depends on the costs and benefits in giving up an exchange rate instrument. With this in mind, the objective of this study is to determine whether fixed exchange rates play a significant role in inflationary performance or whether flexible exchange rates perform as a better shock-absorbing instrument in the Western Balkans. The result reveals that an exchange rate is still the main source of inflationary pressures in Western Balkan countries. Thus policy makers must weigh the relative costs and benefits associated with introducing a flexible exchange rate in small open economies because such regime is likely to incur more costs than benefits.
\end{abstract}

Keywords: Transition economies, Western Ballkan Countries, exchange rate, inflation JEL Classification: E44, F33, P21

\section{INTRODUCTION}

The paper investigates empirically the relationship between exchange rates and inflation in Western Balkan Countries (Albania, Serbia, and Macedonia). Based on the generally accepted macroeconomic theory, many authors (Calvo and Reinhart, 2002; Edwards, 2006) argue that transition countries should apply either fixed exchange rates currency boards or peg their currencies to that of their main trading partners. The main reason for applying rigid exchange rate is that countries in transition show signs of "fear to float" (Edwards, 2006). On the other hand, the empirical evidence that provides argument that exchange rate reacts adversely to real shock by stabilizing the economy, makes a strong case for more accommodative exchange rate as a shock absorber (Blanchard, 2010; Adler and Tovar, 2012). Based on the empirical evidence for transition countries, particularly in the Western Balkan region, exchange rate has often played a fundamental role in macroeconomic stabilization. Looking at the data, it can be seen that from 1996 to the 2014, the rate of inflation has been in single digit in Western Balkan countries. Since, Western Balkan countries in particular, have faced many systemic changes (such as the liberalization of the capital account, becoming members of the World Trade Organization, and gaining candidacy status for joining the European Union) as well as the latest financial crisis (2008), the issue of exchange rate regime has become more pronounced in terms of using the exchange rate as a shock absorber. The empirical evidence for flexible exchange rate is mixed in terms of the role of exchange rate as a shock-absorbing instrument. A very small shock-absorbing role is found for the 
flexible exchange rate for Austria, the Netherlands, France, Italy, Spain and the United Kingdom (see Canzoneri et al., 1996).

A similar conclusion was reached by Thomas (1997) and Funke (2000) in the case of the United Kingdom and Sweden. Artis and Ehrman (2006) who investigated the symmetric and asymmetric shocks for Denmark, Sweden, Canada and the United Kingdom also arrived at a similar conclusion. On the other hand, the study by Coricelli et al. (2005) found no shock-absorbing role of exchange rates in the Check Republic, Hungary, Poland and Slovenia. The analysis by Borghijs and Kuijs (2004) for Central European countries found exchange rates to be less helpful propagator of monetary and financial shocks compared to serving a useful absorber of the real shocks. Recently the study by Shevchuk (2014) made the same conclusion. On the other hand, StażkaGawrisyak (2009) and Dabrowski and Wróblewska (2014) who investigated the exchange rate as a shockabsorber of the adverse effects of the asymmetric real shocks in Poland claimed that the exchange rate has responded as a shock-absorber to real shocks. However, Edwards (2006) who investigated the relationship between exchange rate and inflation in emerging countries and transition countries did not find any evidence of the exchange rate acting as a shock absorber. Recently, Tsangaridis (2012) showed that emerging countries that peg their currencies during the financial crisis were not worse than those that floated. However "peggers" were far worse during the period of recovery 2010-2011. The same result was found by Blanchard (2010) who claims that the fixed exchange rate has a limited effect on output, and growth declined during the crisis. Adler and Tovar (2012) in another recent study showed that exchange rate flexibility can mitigate the impact of the adverse effect of financial shocks, particularly to the emerging economies that are greatly financially integrated.

To summarize, the question of the optimal monetary regime for small open economies is still unanswered. Economists have not been able to determine whether these countries should use floating or fixed exchange rates. Thus the solution of simply shifting the exchange rate from a fixed exchange rate to a more flexible one, so that it could serve as a shock absorber could easily disturb macroeconomic stability without any real shortterm economic benefits. To the best of our knowledge, there are no studies that have investigated the role of exchange rate as a shock-absorbing instrument in the Western Balkans. Hence, we address the issue of whether a fixed exchange rate is more effective than a more flexible exchange rate in serving as a shock absorber in the Western Balkans. Therefore, our efforts in this paper are focused on identifying the effect that exchange rate regimes have on inflation in the Western Balkans. The reminder of the paper is organized as a follows: Section II covers the methodology and data; section III covers the results, and section IV covers the conclusions.

\section{DATA AND METHODOLOGY}

In order to examine the relationship between inflation and exchange rate, we apply panel methods data such as Fixed and Random Effects Model and 'Hausman-Taylor instrumental variables IV' model. With these methods we are able to evaluate the effect of exchange rate changes on inflation in Western Balkan countries from 1996-2014. We used quarterly data covering the 15-year period (1996: Q1 to 2014: Q4) and report the results in 'Poodel OLS', 'Fixed Effects' 'Random Effects' and 'Hausman-Taylor IV' model. Because some of the variables can be considered to be endogenous, they are problematic as exchange rates are considered to be determinants of exchange rates themselves. As a consequence the endogenous independent variables will lead to bias regression coefficient accompanying with this variable (Baltagi, 2009). In order to deal with the problem of endogenity, we use instrumental variables. The Hausman-Taylor instrumental variables IV is considered to be a more appropriate model than the random and fixed effect models. The dependent variable is the consumer price index (CPI) while it at the same time serves as an independent variable of the 'first lagged' term of the CPI (inflation), as well as the exchange rate in logarithm form (Inexchange), and the shortterm interest rates (lending interest rate).

The specification of the Hausman-Taylor model is shown through the following equation:

$y_{i t}=c+B_{1}\left(y_{i t-1}\right)+B_{2} \log \left(E X C H_{i t}\right)+B_{3}\left(L I R r_{i t}\right)+u_{i t}$ 
where:

$\mathrm{y}_{\mathrm{it}}$ - index of consumption prices $\mathrm{CPI}$

c - a constant

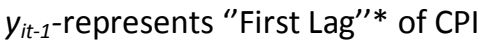

LnEXCHit - logarithm form of exchange rate

Lend_IRr $r_{i t}$ - interest rate of short term loans (lending interes rate)

$u_{i t}{ }^{-}$exogenous disturbances

\section{FINDINGS AND DISCUSSIONS}

Table 1 reports the coefficients of the regression results and all the coefficients are statistically significant. As seen from that Table 1, the results of the regression coefficient of exchange rate is 1.792951 (s.e. 1.103001) and statistically significant. This shows that an increase by $1 \%$ in the exchange rate will have a positive effect on price level by $1.79 \%$, while keeping constant the other variables. This shows furthermore that the flexible exchange rate is a potential source of the inflation in Western Balkans countries. This result is consistent with previous studies, for example Kuijs (2002), Ganev et al., (2002), Coricelli at al., (2005), Bailliu and Fujii (2005), Fetai (2013). The result shows that the flexible exchange rate is the main source of the inflationary pressures in Western Balkans countries. Hence, the policy makers in these countries must take into consideration the relative costs and benefits that come with introducing a flexible exchange rate as shock absorber. Based on the results of this study, a flexible exchange regime is more likely to incur more costs than benefits.

Table 1: The Impact of Exchange Rate on Inflation

\begin{tabular}{lllll}
\hline & \multicolumn{1}{c}{ OLS } & $\begin{array}{l}\text { Fixed } \\
\text { effects }\end{array}$ & Random effects & \multicolumn{1}{c}{$\begin{array}{l}\text { Hausman } \\
\text { Taylor IV }\end{array}$} \\
\hline Variablat & \multicolumn{1}{c}{ CPI } & \multicolumn{1}{c}{ CPI } & \multicolumn{1}{c}{ CPI } & CPI \\
\hline cpiL1 & $0.8588193^{* *}$ & $0.8353863^{* *}$ & $0.8588193^{* *}$ & $0.8515707^{* *}$ \\
Log Exchange & $(-0.0311345)$ & $(-0.0345063)$ & $(0,0311345)$ & $(-0.0329302)$ \\
Lend_IR & $1.116882^{*}$ & $2.128529^{*}$ & $1.116882^{*}$ & $1.792951^{*}$ \\
Constant & $(-0.864495)$ & $(-1.121202)$ & $(-0.864495)$ & $(-1.103001)$ \\
& $-0.2048432^{* *}$ & $-0.2078634^{*}$ & $-0.2048432^{*}$ & $-0.2092824^{*}$ \\
\hline Observations & $(-0.0443571)$ & $(-0.0448472)$ & $(-0.0443571)$ & $(-0.044994)$ \\
R-squared & $-7.115912^{*}$ & $-11.27087^{*}$ & $-7.115912^{*}$ & $-11.17423^{*}$ \\
F & $(-4.098568)$ & $(-5.221626)$ & $(-4.098568)$ & $(-6.341948)$ \\
Chi2 & 191 & 191 & 191 & 191 \\
\hline
\end{tabular}

Note: $\left({ }^{*}\right)$ statistically significant at $5 \%$ level, $\left({ }^{* *}\right)$ statistically significant at $10 \%$ level

We include $L_{-} I R$ (Lending short term interest rate on loans) as a control variable in this study. The result shows that in the lending scenario, an increase in the interest rate by $1 \%$ will have modest and opposite effect on inflation, i.e., it will reduce inflation by $0.2 \%$. This result is also consistent with economic theory as well as previous studies which concluded that there is a negative relationship between inflation and interest rate. To summarize, the exchange rate has a significant effect on inflation, therefore any decision to change current monetary strategy i.e., applying fixed or flexible exchange rate must also take into consideration the associated costs and benefits. Our study has shown that in the case of applying the flexible exchange rate, the associated costs seem to outweigh the benefits. The study suggests that, since Western Balkan countries have to join EUthe exchange rate seems to be the main source of inflation, hence a wise strategy will be to stabilize the 
exchange rate which in turn would lead to lowering inflation and help to fulfill conditions to enter in the EMU (European Monetary Union).

\section{CONCLUSION}

Exchange rates have played a significant role in maintaining price stability in the Western Balkans. Since Western Balkans countries are faced with systemic changes (such as the liberalization of the capital account, becoming a members of the World Trade Organization, and gaining candidacy status for joining the European Union) as well as the latest financial crisis (2008), the question of exchange rate regime becomes more pronounced in terms of using the exchange rate as a shock absorber. Recently, the literature on transition countries has focused on the exchange rate as a shock absorber, but seems to have downplayed the costs with regard to macroeconomic stabilization. We have attempted to address question of whether the fixed exchange rate plays a significant role on the inflation performance or whether the flexible exchange rate should be applied to serve as a shock absorber in the Western Balkans. The main finding of the study is that changes in the exchange rate will have a strong effect on inflation in Western Balkan countries. The result also reveals that the exchange rate is still the main source of inflationary pressures in Western Balkans countries, therefore policy makers in region must weigh seriously the relative costs and benefits associated with introducing a flexible exchange rate regime before making a decision. The results of this study are consistent with the findings of previous studies that held that the stability of the exchange rate plays a significant role in maintaining price stability in transition economies. Furthermore, since Western Balkan countries have to join EU- and exchange rate is the main source of inflation- stabilization of the exchange rate would lower inflationary pressure and help to fulfill some of the criteria to enter the EMU (European Monetary Union).

\section{REFERENCES}

Adler, G. and Tovar, C. E. 2012, "Riding Global Financial Waves: The Economic Impact of Global Financial Shocks on Emerging Market Economies", IMF Working Paper WP/12/188.

Artis, M., and Ehrmann, M. 2006, "The exchange rate _ A shock-absorber or source of shocks? A study of four open economies", Journal of International Money and Finance 25, 874-893.

Blanchard, O. 2010 "Institutions, Markets, and Poland's Economic Performance", Argumenta Oeconomica Cracoviensia 6, 7-11.

Bailliu J, Fujii E, 2005 :"Exchange Rate Pass-Through and the Inflation Environment in Industrialized Countries " Working Paper 2004-21, ISSN 1192-5434.

Baltagi, B. 2009 : "Econometric Analysis of Panel Data", Fourth Edition, London: John Wiley \& Sons Ltd.Bank of New Zealand, (2003), pp. 128

Borghijs, A., and Kuijs, L. 2004, "Exchange Rates in Central Europe: A Blessing or a Curse?", IMF Working Paper WP/04/2, 1-28.

Calvo, G., and Reinhart, M.,K., 2002, "Fear of Floting," Quarterly Journal of Economics.

Coricelli, F., Bostjan, J., Masten, I., 2005: "Exchange rate pass-through in EMU acceding countries: Empirical analysis and policy implication," Journal of banking anf finance, 2005.

Canzoneri, M. B., Vallés Liberal, J.,and Viñals, J. 1996, "Do Exchange Rates Move to Address International Macroeconomic Imbalances?,"

Banco de España - Servicio de Estudios, Documento de Trabajo 9626.

Dabrowski, M. A., and Wróblewska, J. 2014, "Financial shocks as a cause of real exchange rate fluctuations in Poland-evidence from the Bayesian structural VAR models", in: Proceedings of the 8th Professor Aleksander Zelias International Conference on Modeling and Forecasting of Socio-Economic Phenomena, Foundation of the Cracow University of Economics, Cracow, 37-46.

Edwards , S., 2006: "The relationships between exchange rates and inflation targeting revisited", NBER, Working Paper 12163, Cambridge, $1-33$.

Fetai, B 2013: "Exchange rates pass-through in transition economies", Transition Studies Review, vol. 20, 309-324.

Funke, M., 2000: "Macroeconomic shocks in Euroland vs the UK: supply, demand or nominal?" University of Hamburg, Mimeo.

Ganev G, Molnar K, Rybinski K, Wozniak P 2002:" Transmission mechanisms of monetary policy in central and eastern Europe", central for social and economic research, Case Reports No. 0052, Warsaw, pp 1-28. 
Kuijs L., 2002. "Monetary Policy Transmission Mechanisms and Inflation in the Slovak Republic". IMF Working Paper, 80.

Stażka-Gawrisyak, A., 2009: "The Shock-Absorbing capacity of the flexible exchange rate in Poland", Focus on Economic Integartion, 4, 5470 .

Shevchuk 2014, Tsangarides, C. G. 2012, "Crisis and recovery: role of the exchange rate regime in emerging market countries". Journal of Macroeconomics 34, 470-488.

Tsangarides, C. G. 2012, "Crisis and recovery: role of the exchange rate regime in emerging market countries". Journal of Macroeconomics $34,470-488$

Thomas, A., 1997: "The monetray transmission mechanism in Sweeden", IMF working paper, WP/97/176. 